\title{
FEATURE \\ St. Johns Levee and Drainage District attempt to mitigate internal flooding
}

\author{
Lois Wright Morton and Kenneth R. Olson
}

W hen the Mississippi River reaches $87.9 \mathrm{~m}(290 \mathrm{ft})$ above sea level near New Madrid, Missouri, bottomlands adjacent to the river and farmland, roads, ditches and wetlands begin to flood. Concurrently, at the lower end of the New Madrid Floodway the rising Mississippi backs up into Main Ditch (figure 1), the $454 \mathrm{~m}(1,500 \mathrm{ft})$ gap in the frontline levee designed to drain the Floodway and St. Johns Levee and Drainage District to the river (figure 2). When this occurs, the Main Ditch gates on the setback levee (figure 3) are closed to protect the St. Johns Bayou basin from Mississippi River backflow. However, with the Main Ditch gates closed, precipitation within the basin has no outlet as it drains to the Main Ditch channel. This causes tributary streams to back up and flood a substantive portion of agricultural lands and the town of East Prairie, Missouri. For example, the $19 \mathrm{~cm}$ (7.5 in) of rain during the first three days of May of 2011 backed up local floodwater in the St. Johns Bayou basin all the way to East Prairie.

The construction of the Commerce to Birds Point to New Madrid levees (figure 2) artificially separated lands within St. Johns Bayou basin and the New Madrid Floodway from their natural drainage paths to the Mississippi River. While much of the farmland behind these levee systems are protected when the waters of the Ohio and Mississippi rivers exceed flood stage, thousands of hectares (thousands of acres) of bottomlands are flooded through the gap in the lower New Madrid Floodway frontline levee. In addition, the closure of the setback levee gates at the gap results in many more thousands of hectares (thousands of acres) in St. Johns Bayou basin being internally flooded.

Lois Wright Morton is professor of sociology, in the College of Agriculture and Life Sciences, lowa State University, Ames, lowa. Kenneth R. Olson is Professor Emeritus of soil science in the College of Agricultural, Consumer, and Environmental Sciences, University of Illinois, Urbana, Illinois.

\section{Figure 1}

A riverboat on the Mississippi River can be seen passing the outlet of Main Ditch, which drains through the $454 \mathrm{~m}$ frontline levee gap at New Madrid, Missouri, to the Mississippi River.

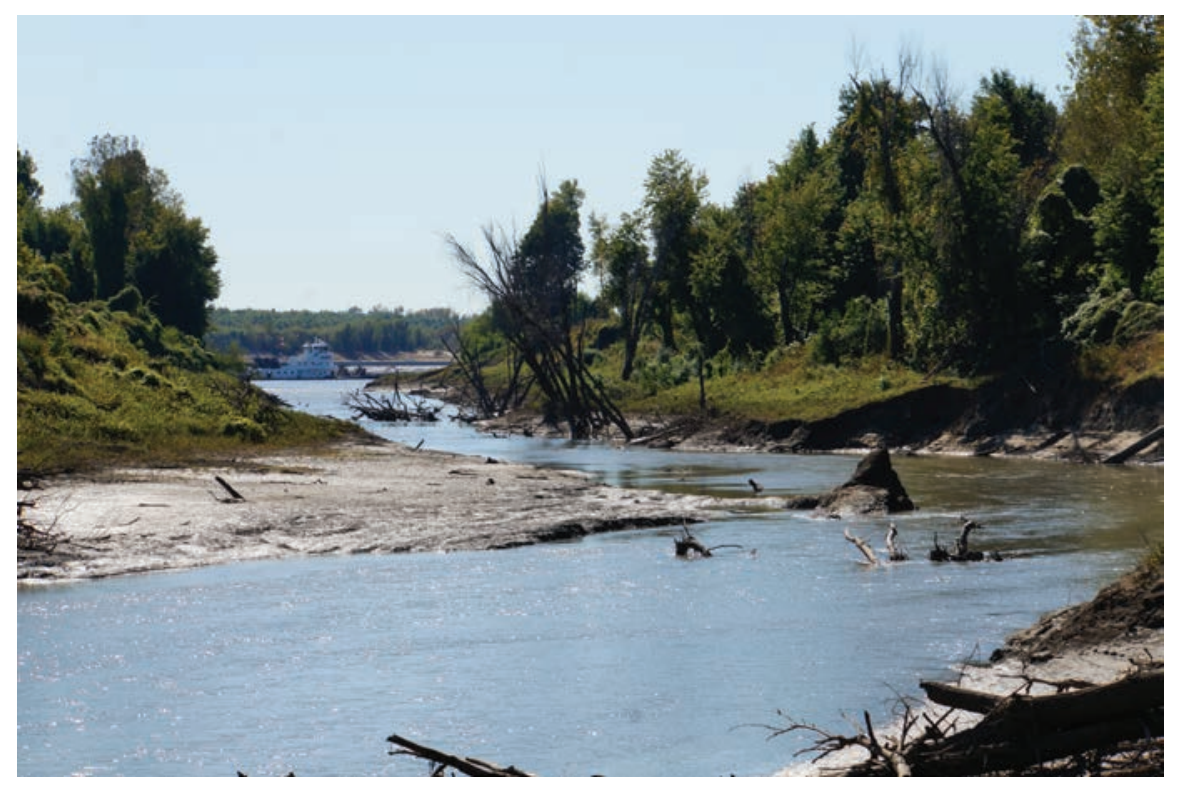

Whenever heavy snowmelt and prolonged rains occur in the upper Mississippi and Ohio river valleys, the people of this region watch the river gage numbers with concern for high water river pressure threats to their levee systems and internal flooding of low-lying areas from drainageways. Table 1 illustrates how different Mississippi River high water events affected the acreages that were flooded in St. Johns Bayou basin and New Madrid Floodway in 1997, 2008, and 2011. The United States Army Corps of Engineers (USACE) has responsibilities for many aspects of the Mississippi River including flood control, river navigation, and floodplain ecosystems. In recent years USACE flood mitigation planning in the Bootheel of Missouri has attempted to reduce the number of days communities are isolated by floodwaters, limit crop and non-crop losses, and reduce damage to critical infrastructure by adopting flexible strategies that reconnect the hydrology of the floodplain to the river.

\section{GEOLOGICAL HISTORY}

Historically the path of the Mississippi River just south of Cape Girardeau turned southwest into the current state of Missouri. It then traveled more than $40 \mathrm{~km}(25 \mathrm{mi})$ to the west (Olson and Morton 2014a) before turning south toward Morley, Missouri, where it joined with the ancient Ohio River waters draining through the Cache River valley (ancient Ohio River valley) (Olson and Morton 2014b). The historic confluence near Morley, Missouri, was 47 km (30 mi) north of the current confluence of the Mississippi and Ohio rivers located south of Cairo, Illinois (figure 2).

The Mississippi River realigned at the end of the Great Ice Age. After the last glacier advance, the melting ice flooded and altered the course of many channels and streams including the Mississippi and Ohio rivers (Olson and Morton, 2013a, 2013b). The $9.3 \mathrm{~km}(6 \mathrm{mi})$ stretch of the Mississippi river just north of Commerce, Missouri, is historically unique (Olson and Morton 2014a).This stretch of the Mississippi River valley is very narrow and lacks the wide 
alluvial bottomland typically found along the Mississippi River. Once the ancient Mississippi Valley was no longer connected to the Mississippi River, the alluvial bottomlands south of Commerce and Benton, Missouri, became a swamp called Tywappity Bottom (figure 2).

The Mississippi River, during this prehistoric period, migrated rapidly by eroding the outside of river bends and depositing sediment on the inside of the bend. Abundant oxbow lakes mark old positions of the channel that have been disconnected from the river. This historic meandering is apparent in the floodway and St. Johns Bayou basins where topographical maps reveal swirls and curves from previous oxbows across the landscape.

\section{THE BOOTHEEL OF MISSOURI}

The Bootheel is the wettest region in the state of Missouri with annual rainfall averaging $1.4 \mathrm{~m}$ (55 in). As a result of its proximity to the Mississippi River, the region experiences frequent headwater and backwater flooding (table 1). Headwater flooding is caused by drainage of rainfall from surrounding uplands. Backwater flooding occurs during seasonally high water events when snowmelt and rain from upstream tributaries raise Mississippi River levels and create backup into riverine bottomlands. When Spanish explorers in the 1700s passed through the area, these southeast Missouri lowlands supported 1 million ha (2.5 million ac) of bottomland hardwood and swamp forests with an occasional slightly higher dry zone of bottomland, which by the late 1800 s could be planted to cultivated crops The soils are rich and fertile, but settlers had difficulty harvesting hardwood timber from wetland soils and swamps. Farming the cleared timber soils was difficult, and the land remained relatively cheap until farmers developed strategies for draining it. The draining of the Tywappity bottomlands south of Benton and Commerce, Missouri (figure 2), was accomplished by clearing and burning of trees and stumps, constructing drainage ditches to aerate the soil, and then cultivation. By 1975 only 40,000 ha $(100,000 \mathrm{ac})$ of original forest remained in both the St. Johns Bayou and the adjacent Little River Levee and Drainage District located to the north, west, and south.

\section{Figure 2}

Map of St. Johns Bayou basin and New Madrid Floodway, Missouri. The systems of levees that protect agricultural lands from Mississippi River flooding have altered the natural internal drainage of both these basins. Map by Mic Greenberg.

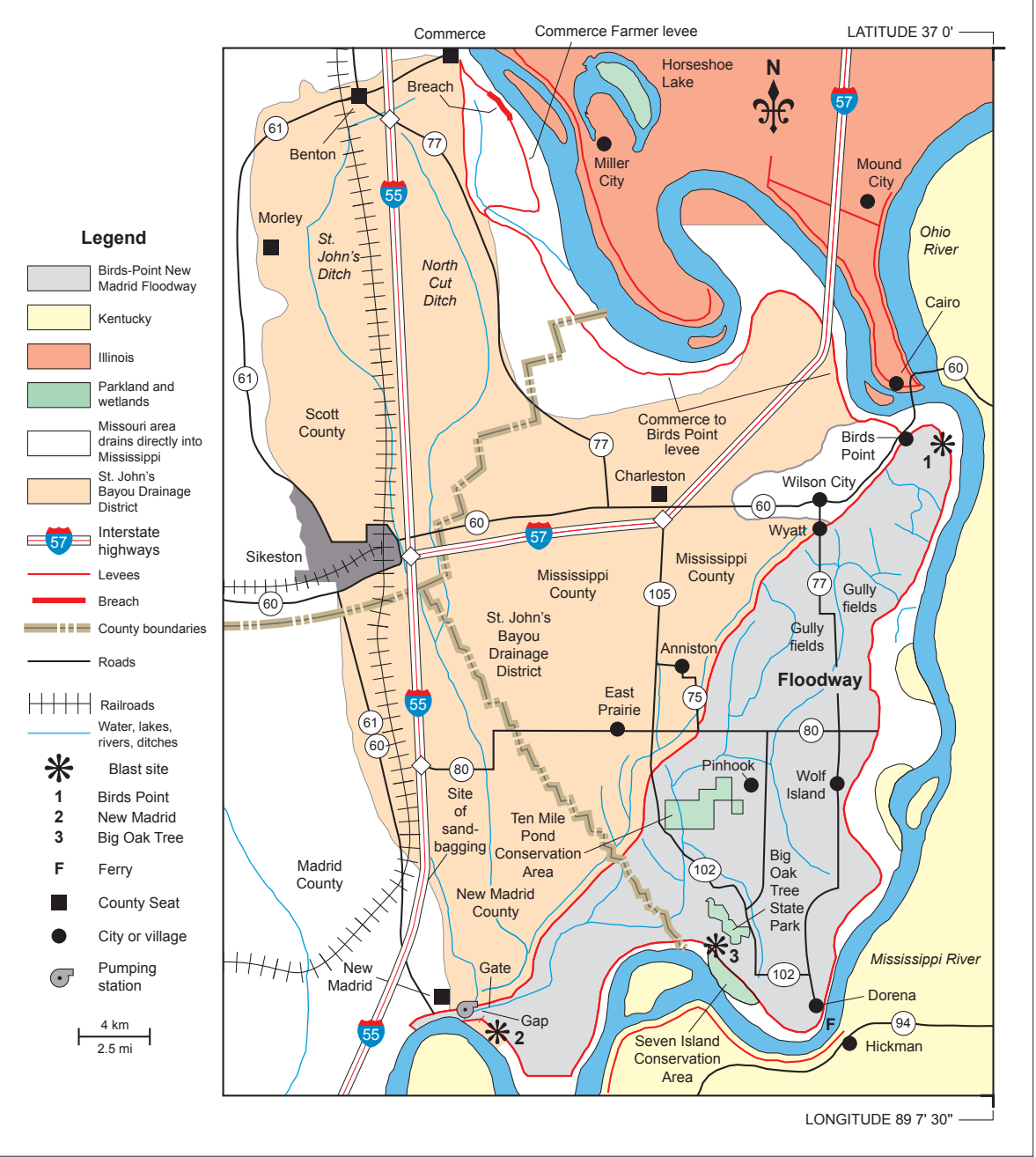

\section{Table 1}

Floodwater heights in 1997, 2008, and 2011 and corresponding area flooded in New Madrid Floodway and the St. Johns Bayou basin.

\begin{tabular}{lllll}
\hline & $\begin{array}{l}\text { Mississippi River } \\
\text { height }(\mathbf{m})\end{array}$ & $\begin{array}{l}\text { Flooding in New } \\
\text { Madrid Floodway } \\
\text { basin (ha) }\end{array}$ & $\begin{array}{l}\text { St. Johns Bayou } \\
\text { basin height }(\mathbf{m})\end{array}$ & $\begin{array}{l}\text { Flooding in St. } \\
\text { Johns Bayou } \\
\text { basin (ha) }\end{array}$ \\
\hline March 16,1997 & 90.4 & 26,780 & 90.0 & 10,152 \\
April 15, 2008 & 90.0 & 23,342 & 89.8 & 14,106 \\
May 1, 2011 & 90.7 & 28,000 & 90.1 & 16,000 \\
\hline
\end{tabular}

\section{COMMERCE, MISSOURI, FARMER LEVEE AND DRAINAGE DISTRICT BREACH}

During the Great Flood of 2011, the Commerce farmer levee located between the USACE Commerce to Birds Point levee and the Mississippi River breached about $3 \mathrm{~km}$ (2 mi) south of Commerce (figure 2). This breach occurred when a sand boil undermined the earthen levee shortly after the New Madrid Floodway was opened on May 2 to relieve the pressure on the floodwalls and levees near the confluence of the Ohio and Mississippi 


\section{Figure 3}

The New Madrid Floodway setback levee gate is used to drain the St. Johns Bayou basin to the Main Ditch and under flood conditions prevents Mississippi River backup water from flowing into the basin.

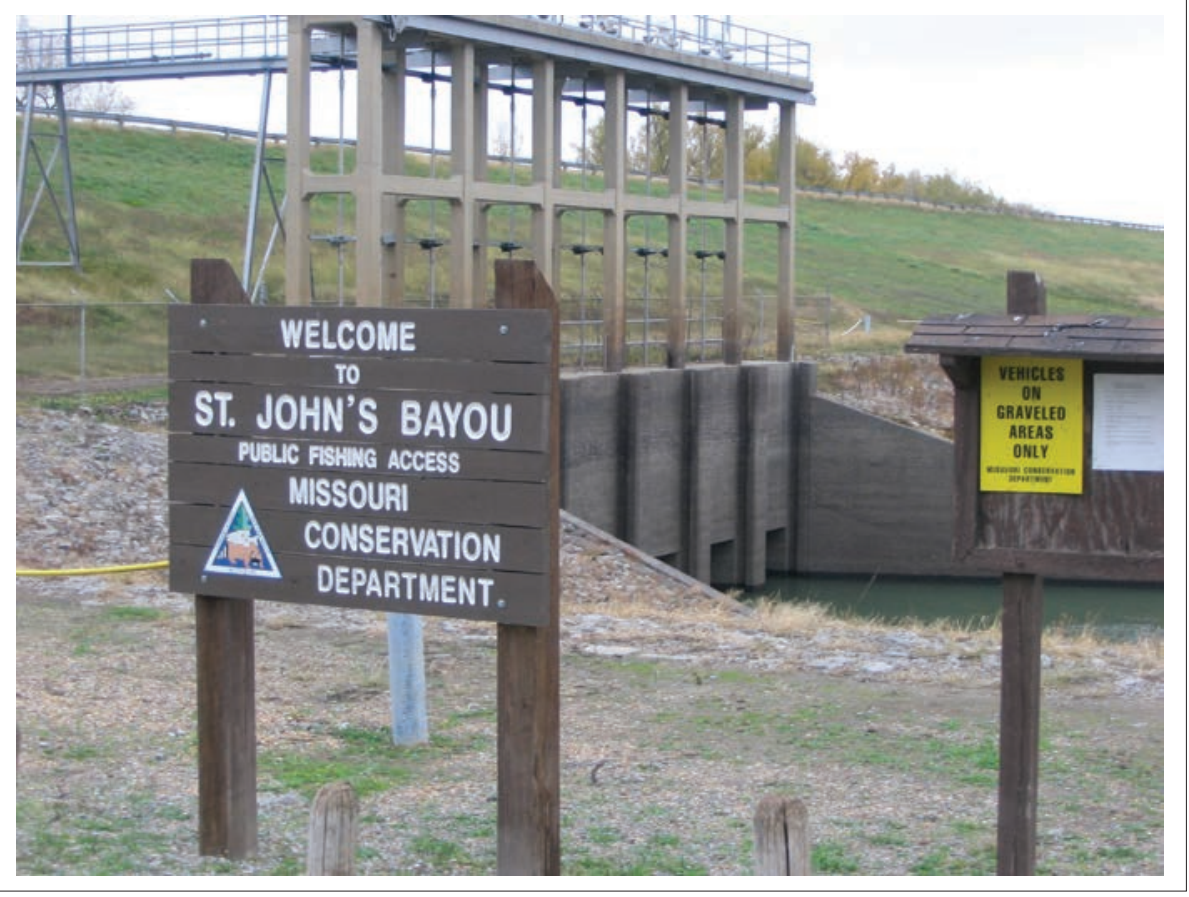

rivers. Floodwaters poured through the Commerce farmer levee breach and covered the entire 2,000 ha $(5,100 \mathrm{ac})$ of agricultural lands within the farmer levee district with a thin organic-clay coating. The entire 2010 winter wheat crop drowned (Olson and Morton 2013a, $2013 b)$. This area drained by the middle of June of 2011, and soybeans were planted. The levee was temporarily repaired in 2011 and fully repaired in the drought year of 2012 (figure 4). The cost of the levee repair raised the drainage district assessment from US $\$ 12.5 \mathrm{ha}^{-1}$ (US\$5 $\mathrm{ac}^{-1}$ ) to US\$62.5 $\mathrm{ha}^{-1}$ $\left(\$ 25 \mathrm{ac}^{-1}\right)$ in 2013. The Commerce to Birds Point levee, located west of the Commerce farmer levee, did not breach and protected 1 million ha (2.5 million ac) of Missouri and Arkansas bottomland (Olson and Morton 2013a, 2013b), including the agricultural lands created from the drained Tywappity bottomlands.

The economic value of the farmer levee system was demonstrated by recent farmland sales. Approximately 200 ha (500 ac) of the 2,000 ha $(5,100 \mathrm{ac})$ located between the Commerce farmer levee and the federal Commerce to Birds Point levee (figure 2) were sold as three separate tracts at an auction on October 21,2013. The winning bids averaged US $\$ 15,000 \mathrm{ha}^{-1}$ (US\$6,100 $\mathrm{ac}^{-1}$ ) plus a US\$900 ha $\mathrm{ha}^{-1}$ (US\$360 $\mathrm{ac}^{-1}$ ) broker fee. At the same time 40 ha (105 ac) of unprotected bottomlands between the farmer levee and the Mississippi River did not sell. A US $\$ 5,000 \mathrm{ha}^{-1}$ (US $\$ 2000$ $\left.\mathrm{ac}^{-1}\right)$ bid was not accepted. The land protected by the Commerce farmer levee was valued at least US $\$ 10,000 \mathrm{ha}^{-1}$ (US $\$ 4,000$ $\mathrm{ac}^{-1}$ ) higher than unprotected land.

\section{THE GAP IN THE BIRDS POINT-NEW MADRID FLOODWAY}

The Birds Point-New Madrid Floodway was built between 1928 and 1932 with a $454 \mathrm{~m}(1,500 \mathrm{ft})$ gap between the frontline and setback levees just northeast of New Madrid, Missouri, to provide an outlet (figure 2) to the Mississippi River when the emergency floodway is opened by the USACE. The creation of the floodway, by the addition of a setback levee 6 to $16 \mathrm{~km}$ (4 to 10 miles) to the west of the frontline levee, had the effect of blocking the St. Johns Bayou basin runoff water from draining freely into the Mississippi River. A gate constructed (figure 3) in the setback levee allowed closure during river flood stage and opening to permit drainage through the Main Ditch when the Mississippi River was low (figure 1). The Main Ditch to the river currently drains approximately 120,000 ha $(300,000 \mathrm{ac})$, including 40,000 ha $(100,000 \mathrm{ac})$ of the floodway and 80,000 ha $(200,000 \mathrm{ac})$ of St. Johns Bayou basin through the gate in the setback levee.

In 1954 Congress first authorized a plan to close the New Madrid Floodway gap between the frontline levee that is located adjacent to Mississippi River at the eastern edge of Birds Point-New Madrid Floodway and the setback levee. Backwater flooding from lower magnitude high water river events has plagued over 32,000 ha $(80,000 \mathrm{ac})$ in the southern portion of the floodway. The Flood Control Act of 1954 sought to address this issue by authorizing construction of a new levee across the $454 \mathrm{~m}(1,500 \mathrm{ft})$ gap near New Madrid and creating a gravity drainage structure. Up to 12,800 ha $(32,000 \mathrm{ac})$ of lowlands near the control structure were planned to be a wetland ponding area. The legislation mandated state and local partners to furnish all lands, easements, rights-of-way, and flowage rights.

In 1959, the St. Johns Levee and Drainage District began acquiring easements within the backwater area from private landowners and succeeded in obtaining easements covering 22,800 ha $(57,000 \mathrm{ac})$. However, landowners closer to the gap who did not want their property used as a ponding area resisted participating in the acquisition effort. These landowners preferred the construction of a pumping station that would remove water from the land. Without the cooperation of these key landowners, the levee district was unable to acquire the remaining 8,600 ha $(21,500 \mathrm{ac})$ necessary to meet the easement requirement (personal communication on August 16, 2014, from Charles Camillo, Mississippi River Commission).

The primary goal of the 1954 plan was to reduce river backwater flooding at the lower end of the floodway to provide yearround access to agricultural roads and fields and protect against lost crops and residential damage when seasonal flooding occurred. However, closing the frontline levee gap 


\section{Figure 4}

The Commerce Farmer Levee and Drainage District-repaired breach is located $3 \mathrm{~km}$ south of Commerce, Missouri. Note the Mississippi River on the right and the crater lake on the left created by the force of water pouring through the breach.

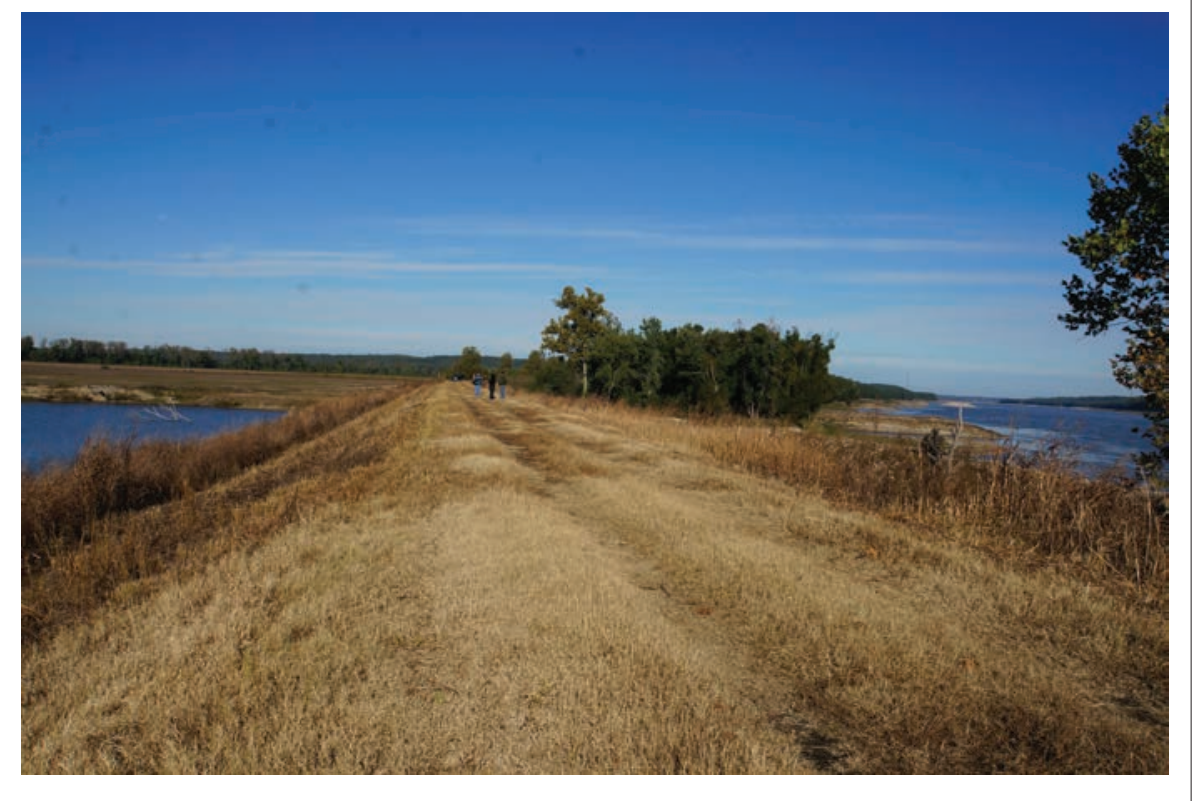

would effectively further disconnect the hydrology of the floodway wetlands, including Big Oak Tree State Park, from the river and impact wetland habitat, waterfowl, shorebirds, fish, and other riverine species that move into flooded areas during the spring rainy season. A 2006 lawsuit by the Environmental Defense Fund and the National Wildlife Federation resulted in a 2007 injunction that halted the work, and the gap remained open.

The aftermath of early snowmelt and heavy spring rains in the upper Mississippi and Ohio River basins resulted in the flood of 2011 and the opening of the floodway for the first time in 74 years (Olson and Morton 2012a, 2012b). It also reignited public conversations about the urgency for internal flood mitigation in both of these basins. During the spring of 2011, the St. Johns Bayou gates were closed to protect against river backwater. However, this caused internal drainage water within the

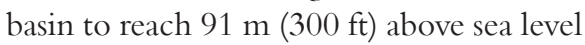
and to back up all the way to Interstate 55. Sandbags were placed on the east side of the interstate to keep floodwaters from blocking traffic on Interstate 55 (figure 2) and disrupting commerce, but the flooding caused considerable damage to residential and agricultural lands.

\section{US ARMY CORPS OF ENGINEERS FLOOD MITIGATION EFFORTS}

Despite an extensive system of levees and internal drainage channels, flooding continues to plague the two basins and limit the agricultural productivity of the region. The USACE reinitiated efforts late in 2006 to close the $454 \mathrm{~m}(1,500 \mathrm{ft})$ frontline levee gap and address the frequent seasonal flooding problems as authorized by 1954 and 1986 legislation at a projected cost of US $\$ 7$ million dollars. However, the levee construction was halted after the National Wildlife Federation and the Environmental Defense Fund filed a federal suit, alleging serious flaws in the USACE analysis of the project's environmental impact (Koenig 2012). Environmentalists claimed that the gap was the last remaining area in Missouri where the Mississippi could reach its floodplain. Further they charged that it would have the largest impact on wetlands of any project in the region that included Missouri, Iowa, Nebraska, and Kansas. In 2007, US District Judge James Robertson ruled that the USACE had acted "arbitrarily and capriciously" by claiming falsely that its plan "would fully mitigate impacts" to the fisheries habitat (Koenig 2012). This ruling blocked the USACE from proceeding with the project and included an order to "deconstruct that portion of the project which was already built." The removal cost an additional US\$10 million dollars. After three years of attempting to close the gap and an expenditure of US $\$ 17$ million, the gap remained open and the town of Pinhook (figure 2) and the lower portion of the floodway continued to flood annually when river water pushed back up the internal drainage system (Koenig 2013).

For many years congressional leaders representing Missouri suggested that environmental groups were exaggerating the project's impact on wetlands and that every backup event from the river had a high economic cost to the region. Bills were proposed to build the levee across the gap and construct a pumping station to keep Mississippi River backwater out of the floodway. The St. Johns Levee and Drainage District is a key local player in attempts to find solutions to these drainage issues. In 2012, two floodway farmers and members of the levee and drainage district's board of supervisors charged that environmental groups were trying to kill the project by conducting a distortion campaign to confuse the public. Taking issue with environmental critics' assertion that closing the levee gap would impede the floodway's future operation and damage the environment, these farmers contended the project would "increase forested lands in St. Johns Bayou Basin by $35 \%$, the Birds Point-New Madrid Floodway by $58 \%$, and triple the size of Big Oak Tree State Park" (Koenig 2012).

The National Wildlife Federation's Water Protection Network analyzed the landownership in the southern part of the floodway, the section in New Madrid County where the backwater problems occur. They reported that approximately 53 landowners or firms would likely benefit from closing the levee gap as well as the village of Pinhook, which was so badly damaged in the 2011 flood that it was vacated (Morton and Olson 2013). Big Oak Tree State Park, one of the last forested wetland remnants located in the lower portion of the floodway, provides a small sanctuary for many local species of flora and fauna, including several state and national trees of record (black willow [Salix nigra]; pumpkin ash [Faxinusprofunda]; 
persimmon tree [Dispyros virginiana]; burr oak [Quercus macrocarpa]; and swamp chestnut oak [Quercus michauxii]). There is some evidence that this park is already threatened by drainage channels (Morton and Olson 2013), which can bring pesticides from surrounding cropland into the park and weaken the hydrological connections to the river. In 2011 floodwater from the induced breach and use of the floodway covered the Big Oak Tree State Park and pond (figure 5). This flooding may have resulted in transporting weeping willow (Salix babylonica) seedlings, an invasive species, into the pond; these willows germinated and grew, and seemed to be crowding out native species during the drought of years 2012 and 2013. Also of concern is the bald cypress (Taxodium distichium), which historically formed dense forests in these swamplands but shows stress after the drought of 2012.

\section{ENVIRONMENTAL IMPACT STATEMENT AND PUBLIC MEETINGS}

Changes in land use and drainage modifications over time have altered the hydrology of St. Johns Bayou and New Madrid Floodway basins. The USACE estimates $86 \%$ of the historical bottomland hardwood forest in the region has been converted to cropland. In 2013 the USACE (2013) prepared a draft environmental impact statement analyzing several flood mitigation scenarios to address the frequent flooding of agricultural, commercial, and residential areas within the basins (USACE Memphis District 2013). Alternative scenarios proposed a variety of modifications to the current infrastructure (e.g., levee gap closure, pumping stations, ditch modifications, ring levee around town of East Prairie, or raised road surface elevations) and changes in land use (e.g., relocate the town of East Prairie, expand or modify existing wildlife refuges, convert nonflood tolerant crops to flood tolerant crops, or convert agricultural crops to silviculture). The USACE evaluated these alternatives based on their ability to achieve three key planning objectives: (1) reduce the number of days that communities are isolated by floodwaters, (2) reduce crop and non-crop agricultural damage, and (3) reduce critical infrastructure damages to streets and roads.

Environmental impact analyses examined simulated interior water surface

\section{Figure 5}

The pond at Big Oak Tree State Park, a remnant forested wetland, as viewed on October 24, 2013, after the flood of 2011 and drought of 2012.

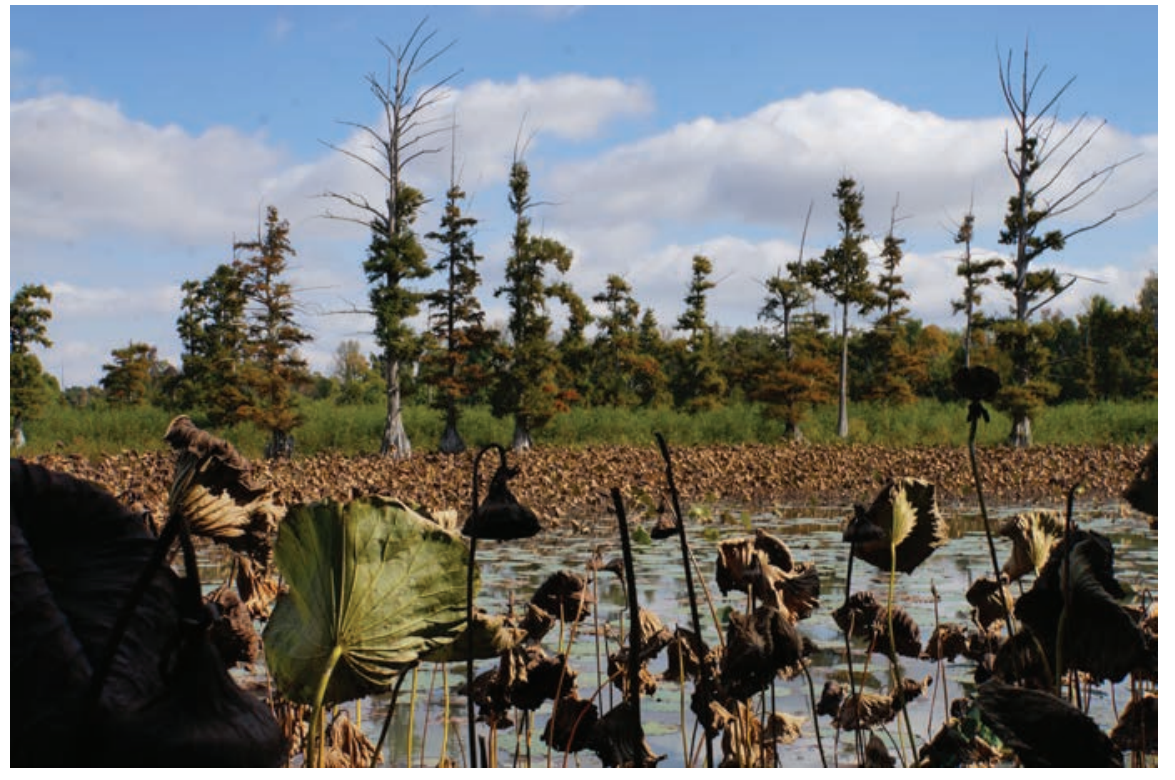

elevations from 1943 to 2009; riverine and $\mathrm{ft})$ gated structures within the $454 \mathrm{~m}(1,500$ permanent fish species; resident, migrating, and overwintering waterfowl; shorebirds that forage in areas of sparse vegetation such as harvested agricultural lands; and wetlands. The wetlands have three classifications: (1) low gradient riverine backwater wetlands frequently flooded by low velocity slack water; (2) low gradient riverine overbank wetlands that frequently flood along or near stream banks or islands within the river channel; and (3) connected depression wetlands, which are remnants of abandoned stream channels or swales left behind by migrating channels.

The USACE held two public meetings (on August 27, 2013, in East Prairie, Missouri, and August 28, 2013, in Cairo, Illinois) to present their findings and obtain citizen input on the proposed US $\$ 170$ million flood control project with mitigation elements that compensated for multiple impacts. In the St. Johns Bayou basin they proposed: (1) channel enlargement and vegetative clearing extending from the gate in the setback levee outside New Madrid up the St. James Ditch to the East Prairie area and (2) a $28.3 \mathrm{~m}^{3} \mathrm{~s}^{-1}\left(1,000 \mathrm{ft}^{3} \mathrm{~s}^{-1}\right)$ pump to move water over the levee and into the river when the river gate is closed. At the bottom of the floodway, the USACE proposed a closer levee with four 3 by $3 \mathrm{~m}$ (10 by 10 $\mathrm{ft}$ ) gap that could be closed and opened seasonally to allow the river to come into the floodway at the lowest elevations in order to retain hydrologic connectivity to the river and wildlife pools while reducing flooding of 16,240 ha $(40,597 \mathrm{ac})$ of agricultural lands. When the proposed gate is closed, a $42.5 \mathrm{~m}^{3} \mathrm{~s}^{-1}\left(1,500 \mathrm{ft}^{3} \mathrm{~s}^{-1}\right)$ pump would manage the interior drainage elevations until the Mississippi River dropped sufficiently to allow for gravity drainage.

Public testimony at the Cairo, Illinois, and East Prairie, Missouri, hearing sites revealed strident differences among rural leaders and landowners of the two basins; outside environmental interests; and upstream Cairo, Illinois, residents and rural Illinois counterparts who experienced historical and recent levee breaching and agricultural land flooding. Underlying these differences were the geographical impacts experienced from the flood of 2011 and actions by the USACE to induce levee breaching of the Birds PointNew Madrid frontline levee, placing in use the floodway to prevent massive levee and floodwall failures along the Mississippi River (Olson and Morton 2012b).

The channel modifications and addition of a $28.3 \mathrm{~m}^{3} \mathrm{~s}^{-1}\left(1,000 \mathrm{ft}^{3} \mathrm{~s}^{-1}\right)$ pump in St. Johns Bayou were generally supported by 
local Missouri landowners, elected officials, and environmentalists. A local leader representing St. Johns Bayou Basin framed the human and agricultural economic concerns, "[the basin] has about 1,246 km² (481 $\left.\mathrm{mi}^{2}\right) \ldots 34,000$ residents, 1,046 drinking wells, and produces almost US\$600 million a year income... [we] agree with the drainage ditch proposal and of course the pump station idea..."One environmentalist began his testimony in East Prairie by claiming common ground, "....we support fixing the drainage problems that have been plaguing your community [St. Johns Bayou] for so long. [It's] a problem that affects people, it affects roads, it affects infrastructure; and it needs to be fixed."

However, there was strong opposition from local Missouri landowners in both basins to converting existing farmland into wetland reserves, or allowing farmland to be seasonally inundated to provide wildlife habitat. Environmentalists representing a variety of state and national groups asked the USACE to decouple the flood mitigation strategies in St. Johns Bayou from the floodway levee gap closure. Speaker after speaker in the East Prairie public hearing reminded the USACE that this was a flood control project not an ecological restoration project. Further, there was strong sentiment from local speakers and the audience that the two basin proposals not be decoupled. One speaker received prolonged applause when he said, “...1950s, our communities since then have been standing together, trying to get this project done. We refuse to accept that this project can't be done... this project is about neighbors...providing flood protection on both sides of that setback levee..."

Illinois landowners, Mayor Tyrone Coleman of Cairo, and environmental groups testified at East Prairie and Cairo locations and were strongly opposed to closing the floodway gap near New Madrid.The groups were concerned that building a new levee would, in the words of one speaker, increase "...opportunities for more intensified agriculture in the area." Illinois residents were worried this would increase political pressure to not open the floodway when needed in the future and put the Cairo floodwall and levee system at a greater risk of failure (Lopez-Llompart and Kondolf 2015).
The Illinois landowner opposition was led by homeowners and farmers who had put sandbags around their residences during the 2011 flood. The Len Small levee breach in Illinois occurred on the morning of May 2, 2011, and flooded their homes just hours before the floodway was opened to relieve the pressure on the confluence area levees and Cairo floodwall. These homeowners were convinced that had the New Madrid floodway opening not been delayed but opened according to the 1986 operational plan, they would have been able to save their homes from flood damage.

Environmentalists worried that closing the last quarter mile opening connecting the Mississippi River to its flood plain would "result in loss of critical wetlands for fisheries and wildlife whose unique value is their dynamic relationship with the river." They further claimed that agriculture in the floodway was "already profitable and reliable" and did not need taxpayers to pay for the costs of pumps and levee fortification.

\section{DISCUSSION AND CONCLUSIONS}

The construction of levees and the Birds Point-New Madrid Floodway separated the land in the floodway and St. Johns Bayou basins from their natural drainage pathways. The St. Johns Levee and Drainage District has tried for 83 years to regain access to drain local basin internal floodwater directly to the Mississippi River. Once the floodway setback levee was built, local landowners within the floodway had to sign easements, in 1930s and 1960s, giving USACE the right to pass floodwater over their land. If the floodway had never been built, both the St. Johns Bayou and New Madrid Floodway basin farmers would still have been affected by Mississippi River floodwaters every time the river reached flood stage. However, when the setback levee gate is closed there is no effective way for the local St. Johns Bayou basin runoff to drain to the Mississippi River. If the St. Johns Bayou phase of the USACE project is built, it would appear to allow the local St. Johns Bayou basin floodwater to be pumped over the setback levee during the times when the gate is closed. This should reduce internal flooding in the St. Johns
Bayou basin, which has adversely affected agricultural production and constrained the intensification of agricultural land use.

A primary USACE goal of the US $\$ 170$ million project is to reduce river backwater flooding at the lower end of the floodway to provide year-round access to agricultural roads and fields and protect against lost crops and residential damage when seasonal flooding occurs. However, closing the floodway frontline levee gap would effectively further disconnect the hydrology of the floodway wetlands, including Big Oak Tree State Park, from the river and impact wetland habitat, waterfowl, shorebirds, fish spawning, and other riverine species that move into flooded areas during spring floods. The USACE project attempts to both mitigate the internal flooding experienced in St. Johns Bayou basin and to mitigate the impact on the hydrology of the floodway wetlands, water fowl, shore bird, fish spawning and other riverine species. The project mitigations would not be met by funding the St. Johns Bayou basin phase only. Both mitigation goals could be met if both St. Johns Bayou and floodway gap closing phases of the project are implemented, including land use change, drainage ditch realignment, and building pump stations in both basins.

One of the USACE's greatest challenges is to manage variable river conditions - the uncertainties associated with the concentration and flow of water, and unpredictable weather and changing climate conditionswhile balancing diverse and competing river commerce, agricultural, residential, and environmental interests. The building of the floodway introduced a new era in engineering design, moving from the confinement of levees only (Barry 1997) to a dispersion strategy that allowed the river to temporarily spill into its natural bottomlands to relieve flooding pressures on urban settlements and downstream levees (Camillo 2012). Paradoxically these infrastructure investments intended to reduce direct risks of flooding have led to interior flooding problems and unexpected consequences to the larger ecosystem. Levees have been a critical infrastructure in opening new lands to agricultural production, but they may be inadequate as the distribution, seasonality and intensity of precipitation patterns change (Morton and Olson 2014). Given 
the economic and social constraints, the Mississippi River floodplains are not likely to be fully restored as wetlands to mitigate flood hazards. However, there is a need for a new kind of engineering, one that offers greater resilience to the floodplain system (Park et al. 2012). Resilience engineering goes beyond the levees and floodway structures to strategically reconnect the hydrology of levee protected lands, portions of former wetlands, and the river, thereby ensuring valuable and necessary ecological functions, such as floodwater storage and wildlife habitat, are in place to absorb future uncertainties associated with flooding.

\section{ACKNOWLEDGEMENTS}

Partial support for this research was provided by the Iowa Agriculture and Home Economics Experiment Station, College of Agriculture and Life Sciences at Iowa State University and in cooperation with North-Central Regional Project No.1190, Catalysts for Water Resource Protection and Restoration Applied Social Science Research. Additional funding support comes from Regional Research Project No. 15-372 and in cooperation with North-Central Regional Project No. NCERA-3 Soil Survey; and published with funding support from the Director of the Illinois Office of Research, College of Agricultural, Consumer, and Environmental Sciences, University of Illinois, Urbana, Illinois.

\section{REFERENCES}

Barry, J.M 1997. Rising Tide: The Great Mississippi Flood of 1927 and How it Changed America. New York: Simon and Schuster.

Camillo, C.A. 2012. Divine Providence: The 2011 Flood in Mississippi River and Tributaries Project. Vicksburg, MS:The Mississippi River Commission.

Koenig, R. 2012. Corps balancing levee repairs on Missouri, Illinois sides of Mississippi. St. Louis Beacon. July 30, 2012.

Koenig, R. 2013. Environmental groups bash new impact statement on St. John's Bayou project. St. Louis Beacon. July 19, 2013.

Lopez-Llompart, P., and G.M. Kondolf. 2015. Encroachment in floodways of the Mississippi River and Tributaries project. Natural Hazards, doi: 10.1007/S1169-015-2094-y.

Morton,L.W., and K.R. Olson. 2013. Birds Point-New Madrid Floodway: Redesign, reconstruction and restoration.Journal of Soil and Water Conservation 69(2):35A-40A, doi:10.2489/jswc.69.2.35A.

Morton, L.W., and K.R. Olson. 2014. Addressing soil degradation and flood risk decision mak- ing in levee protected agricultural lands under increasingly variable climate conditions. Journal of Environmental Protection 5:1220-1234.

Olson, K.R., and L.W. Morton. 2012a. The impacts of 2011 induced levee breaches on agricultural lands of Mississippi River Valley. Journal of Soil and Water Conservation 67(1):5A-10A, doi:10.2489/jswc.67.1.5A.

Olson, K.R., and L.W. Morton. 2012b. The effects of 2011 Ohio and Mississippi River valley flooding on Cairo, Illinois, area. Journal of Soil and Water Conservation 67(2):42A-46A, doi:10.2489/ jswc.67.2.42A.

Olson, K.R., and L.W. Morton. 2013a. Impacts of 2011 Len Small levee breach on private and public Illinois lands. Journal of Soil and Water Conservation 68(4):89A-96A， doi:10.2489/ jswc.68.4.89A

Olson, K.R., and L.W Morton. 2013b. Soil and crop damages as a result of levee breaches on Ohio and
Mississippi rivers. Journal of Earth Sciences and Engineering 3:139-158.

Olson, K.R., and L.W. Morton. 2014a. Dredging of the fracture bedrock lined Mississippi River channel at Thebes, Illinois. Journal of Soil and Water Conservation 69(2):31A-35A, doi:10.2489/ jswc.69.2.31A.

Olson, K.R., and L.W. Morton. 2014b. Ohio River flooding of the Cache River Valley in Southern Illinois. Journal of Soil and Water Conservation 69(1):5A-10A, doi:10.2489/jswc.69.1.5A.

Park, J.T., P. Seager, S.C. Rao, N. Convertino, and I. Linkov. 2012. Integrating risk and resilience approaches to catastrophe management in engineering systems. Risk Analysis 33(3):356-367

USACE (US Army Corps of Engineers) Memphis District. .2013.August 27th, East Prairie, Missouri, and August 28, Cairo, Illinois. Public Hearing for the Draft Environmental Impact Statement on St. Johns Bayou- New Madrid Floodway Project. 